НАУКОВИЙ ВІСНИКК

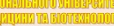

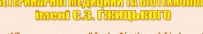

(2)

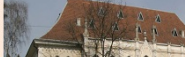

10 MIMIII

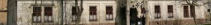

СЕРЯ: ХАРЧОВі ТЕХНОЛОГ

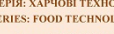

Том 23 № 96

2021
Науковий вісник Дьвівського національного університету ветеринарної медицини та біотехнодогій імені С.3. Гжицького.

Серія: Харчові технології

Scientific Messenger of Lviv National University of Veterinary Medicine and Biotechnologies.

Series: Food Technologies https://nvlvet.com.ua/index.php/food

UDC 637.52:639.3

\title{
Research on changes of the quality indicators of semi-finished products during during storage
}

N. Holembovska

National University of Life and Environmental Sciences of Ukraine, Kyiv, Ukraine

Article info

Received 09.04.2021

Received in revised form 10.05.2021

Accepted 11.05.2021

National University of Life and Environmental Sciences of Ukraine, Colonel Potekhin Str., 16, Kyiv, 03041, Ukraine.

Tel. : +38-096-206-62-76

E-mail:natashagolembovska@gmail.com
Holembovska, N. (2021). Research on changes of the quality indicators of semi-finished products during during storage. Scientific Messenger of Lviv National University of Veterinary Medicine and Biotechnologies. Series: Food Technologies, 23(96), 23-27. doi: 10.32718/nvlvet-f9605

Considering the results of literary studies on the nutritional value and biological efficiency of cranberries and goji berries, it has been established that the development of the technology of semi-finished minced products with their use is relevant and has practical importance in the production of fish products. The article deals with the results of the chemical composition, organoleptic evaluation, and physical and chemical changes in semi-finished minced products with the addition of non-traditional raw materials and the establishment of their shelf life. The expediency of combining freshwater fish with plant material to expand the range of biologically valuable food products is presented in the article. The general positive impressions, harmonious, fish and sweet-salty taste, have shown the expediency of combining cranberries and goji berries with freshwater fish, as evidenced by high levels of appearance, taste, and smell. In terms of consistency, fish cutlets are plastic and dense on the cut. It has been found that there are processes of hydrolytic damage in the control sample after 90 days of storage, which indicates the intensive lipid hydrolysis and the accumulation of free fatty acids in these samples. In experimental samples, hydrolytic damage gradually increases and reaches its critical point only close to the end of the shelf life. Oxidation processes in the lipids of semi-finished products were studied by changes in the accumulation of primary oxidation products - peroxides and secondary products - carbonyl compounds. According to the dynamics of changes in the peroxide value of lipids of semi-finished products, it has been established that the control sample for 60-135 days has not been subjected to storage, and in experimental samples after 135 days, the quality of the fat deteriorates and is characterized as the one that is not subjected to storage. The research has established that the use of non-traditional raw materials in the production of semi-finished minced products allows to improve the technology of production and solve the problem of obtaining the product of a high nutritional value. The authors found that the developed technology of production of semi-finished fish products will significantly expand the range of products of functional purpose based on natural components, which will allow, to some extent, to broaden the current problem of processing raw materials from domestic reservoirs in Ukraine.

Key words: fish sticks, non-traditional raw materials, cranberries, goji berries, semi-finished products, organoleptic evaluation.

\section{Дослідження змін показників якості напівфабрикатів під час зберігання}

\author{
Н. В. Голембовська
}

Національний університет біоресурсів та природокористування Украӥни, м. Київ, Украӥна

Враховуючи результати літературних досліджень, щуодо харчової цінності та біологічної ефективності ягід журавлини та годжі, встановлено, шео розробка технологї напівфабрикатів з їх використанням є актуальною і має практичне значення у технологї виробництва рибних продуктів. У статті представлені результати хімічного складу, органолептичної оцінки та фізикохімічних змін напівфабрикатів з додаванням нетрадиційної сировини та встановлення їх терміну зберігання. Показано доцільність поєднання прісноводної риби з рослинною сировиною для розширення асортименту біологічно цінної харчової продукиії. Отримані позитивні загальні враження, гармонійний, рибний та солодкувато-солонуватий смак, показали доцільність поєднання ягід жура- 
влини та годжі з прісноводною рибою про, щчо свідчать високі показники зовнішнього вигляду, смаку та запаху. За показником консистенції рибні палички пластичні та щільні на розрізі. Було встановлено, щзо в контрольному зразку після 90 діб зберігання проходять прочеси гідролітичного псування, щзо свідчить про інтенсивний гідроліз ліпідів і накопичення вільних жсирних кислот у цих зразках. У дослідних зразках поступово збільшується гідролітичне псування і лише до кінця терміну зберігання досягає критичної точки. Окислювальні прочеси в ліпідах напівфабрикатів вивчали по змінах у накопичуванні первинних продуктів окислення перекисів і вторинних продуктів - карбонільних сполук. За динамікою змін перекисного числа ліпідів напівфабрикатів встановлено, що контрольний зразок протягом 60 - 135 діб не підлягає зберіганню, а в дослідних зразках після 135 днів якість жиру погіриується та характеризується як той, щзо не підлягає зберіганню. Дослідним шляхом встановлено, щуо додавання нетрадиційної сировини дозволяє не лише удосконалити технологію виробництва січених напівфабрикатів, а й вирішити завдання отримання продукту підвищеної харчової иінності. Авторами було встановлено, щзо розроблена технологія рибних напівфабрикатів, значно розщирить асортимент продуктів функціонального призначення на основі природних компонентів, щуо дозволить певною мірою розцирити актуальну проблему перероблення сировини внутрішніх водойм Украӥни.

Ключові слова: рибні палички, нетрадиційна сировина, ягоди журавлини, ягоди годжі, напівфабрикати, органолептичне оцінювання.

\section{Встуі}

У рибній промисловості важливу роль відіграє раціональне використання сировинної бази, оскільки на виробництво риба надходить 3 механічними пошкодженнями, різних розмірів, з дефектами. Технологія 3 виготовлення рибних формованих напівфабрикатів відкриває нові можливості в галузі раціонального використання вторинної рибної сировини, дозволяє розширити асортимент рибних продуктів (Ivaniuta et al., 2021).

Біологічно активні харчові речовини належать до природних компонентів їжі й володіють вираженим фізіологічним і фармакологічним впливом на основні регуляторні та метаболічні процеси організму. Поряд 3 цим, вони $\epsilon$ ефективним способом боротьби з авітамінозом (Monastyrskij, 2004; Holembovska et al., 2021). Біологічно активні харчові речовини містяться в сучасній технології виробництва харчових продуктів рослинної сировини: дикорослих і культивованих ягодах, які широко поширені в країні. В цілому дикорослу сировину слід розглядати, як джерело надходження в організм людини харчових волокон (Shapiro et al., 2003).

Зараз актуальною темою є збагачення повсякденного раціону біологічно активними речовинами. Вони ефективно усувають дефіцит вітамінів, органічних кислот i мінеральних речовин. Споживання в їжу продуктів, які несуть негативний вплив на наш організм, примушує переглянути правила сучасного харчування.

Використання нетрадиційної рослинної сировини, як ягід журавлини, годжі та внесення їх в рецептуру, дозволяє збагатити раціон біологічно активними речовинами, отримати високоякісні вироби з хорошими органолептичними показниками, а також розширити асортимент вже наявних страв (Golembovskaya, 2019).

Мета $і$ завдання дослідження. Метою проведених досліджень є визначення біологічної цінності нових рибних напівфабрикатів (рибних паличок) на основі поєднання прісноводної риби (короп) та нетрадиційної сировини (ягоди журавлини та годжі).

Відповідно до поставленої мети були визначені наступні завдання: розробка рецептурного складу та технології напівфабрикатів 3 прісноводної риби 3 використанням нетрадиційної сировини; дослідження змін якості напівфабрикатів під час зберігання за органолептичними показниками; проведення комплексної оцінки якості готових продуктів в процесі зберігання.

\section{Матеріал і методи досліджень}

Як основну сировину в експериментальних дослідженнях використовували коропа весняного та осіннього вилову згідно з ДСТУ 2284 (DSTU 2284-93), які були вирощені у водосховищах ПАТ “Черкаси рибгосп”, журавлина згідно з ДСТУ 5035:2008 та ягоди годжі згідно з ТУ У 15.8-00481181-018:2016.

Підготовку проб досліджуваних зразків для органолептичних, фізико-хімічних i мікробіологічних досліджень здійснювали за ГОСТу 7636-85 (GOST 7636-85), відбір проб проводили відповідно до ГОСТу 7631-85 (GOST 7631-85).

Характеристику хімічного складу рибних напівфабрикатів проводили за наступними методиками: масову частку вологи методом висушування зразка продукту до постійної маси за температури $100-105{ }^{\circ} \mathrm{C}$; масову частку золи - ваговим методом, після мінералізації наважки продукту в муфельній печі за температури 500-600 ${ }^{\circ} \mathrm{C}$; масову частку ліпідів методом Сокслета; масову частку білка визначенням загального азоту за методом Кьельдаля. Озолення зразків проводили на Velp Scientifica cepiï DK6 (Італія) та відгону на апараті для перегонки 3 парою Velp Scientifica UDK 129 (Італія) (GOST 7636-85).

\section{Результати та їх обговорення}

На перших етапах роботи були проведенні дослідження рослинної сировини.

Результати досліджень органолептичних показників ягід журавлини та годжі наведені у таблиці 1.

Фізико-хімічні показники ягід журавлини наведені в таблиці 2. 
Таблиця 1

Органолептичні показники ягід журавлини та годжі

\begin{tabular}{|c|c|c|}
\hline \multirow{2}{*}{ Показники } & \multicolumn{2}{|c|}{ Біологічно активні добавки } \\
\hline & Журавлина & Годжі \\
\hline $\begin{array}{l}\text { Зовнішній вигляд та } \\
\text { консистенція }\end{array}$ & \multicolumn{2}{|c|}{$\begin{array}{c}\text { ягода темно-червона, кулястої або еліпсоїдної форми діаметром до } 12 \text { мм, без видимих } \\
\text { включень та домішок }\end{array}$} \\
\hline $\begin{array}{l}\text { Смак та } \\
\text { запах }\end{array}$ & Соковитий, кислий & $\begin{array}{l}\text { Приємний соковитий, кислий смак злегка з гіркува- } \\
\text { тим присмаком }\end{array}$ \\
\hline Колір & $\begin{array}{l}\text { Від світло до темно- червоного кольору, } \\
\text { однорідний за всією масою }\end{array}$ & Темно-червоний, однорідний за всією масою \\
\hline
\end{tabular}

Таблиця 2

Фізико-хімічні показники ягід журавлини

\begin{tabular}{ccccc}
\hline Назва сировини & Сухі речовини, \% & Вітамін С, мг/100 г & Пектини, г & Титрована кислотність, \% \\
\hline Журавлина & 24,2 & 7,04 & 0,84 & 2,75 \\
\hline
\end{tabular}

Основний компонент сухих речовин - цукор. Моноцукри, представлені в плодово-ягідній сировині, завжди знаходяться 3 мінеральними солями. Вміст в ягодах глюкози та фруктози приблизно однаковий, сахарози практично немає.

Хімічний склад ягід журавлини та годжі представлені в таблиці 3 .

Таблиця 3

Хімічний склад ягід журавлини та годжі

\begin{tabular}{lcc}
\hline \multicolumn{1}{c}{ Назва показників } & Журавлина & Годжі \\
\hline Масова частка вологи, \% & 80,9 & 12 \\
Цукор, \% & 6,2 & - \\
Пектинові речовини, \% & $0,6-3,3$ & 2,4 \\
Клітковина, \% & $1,4-1,6$ & 3,1 \\
\hline
\end{tabular}

Аналізуючи представлені дані, можна зробити висновок про різноманітність хімічного складу ягід, який залежить від виду, сорту, умов проростання i термінів збору врожаю.

При розробці рецептур враховувалися норми потреб, рекомендовані ФАО ВООЗ. Як контроль було взято зразок напівфабрикатів, виготовлений без рослинних добавок. Рецептура контрольного та дослідних зразків представлена у таблиці 4.

\section{Таблиця 4}

Рецептури рибних паличок з добавками

\begin{tabular}{cccc}
\hline \multirow{2}{*}{$\begin{array}{c}\text { Найменування } \\
\text { компонентів }\end{array}$} & \multicolumn{3}{c}{ Рецептурний склад, кг на 100 кг } \\
& продукції \\
\cline { 2 - 4 } Фонтроль & Зразок 1 & 3разок 2 \\
\hline Філибний & 78,92 & 76,92 & 76,92 \\
Яйця в фарш & 1 & 1 & 1 \\
Хліб & 5 & 5 & 5 \\
Вода & 8 & 8 & 8 \\
Крохмаль & 5 & 5 & 5 \\
Перець чорний & 0,06 & 0,06 & 2 \\
Перець духмяний & 0,02 & 0,02 & 0,06 \\
Журавлина & - & 2 & 0,02 \\
Годжі & - & - & - \\
\hline
\end{tabular}

При виробництві формованих напівфабрикатів використовували рідке тісто рецептура якого наведена в таблиці 5 .

\section{Таблиця 5}

Рецептура рідкого тіста

\begin{tabular}{lc}
\hline \multicolumn{1}{c}{ Найменування } & Рецептурний склад рідкого \\
компонентів & тіста, кг на 100 кг \\
\hline Борошно пшеничне & 32 \\
Крохмаль & 5 \\
Сіль & 1,5 \\
Яйця курині & 3 \\
Вода & 60 \\
\hline
\end{tabular}

Комбінування прісноводної рибної сировини з рослинною дає змогу оптимізувати смакові властивості готового продукту, біологічну цінність та продовжити термін зберігання.

3 метою оцінки якості готових виробів проводили дослідження їх хімічного складу. Отримані результати наведені в таблиці 6.

Згідно 3 проведеним аналізом хімічного складу спостерігаємо вміст вологи у зразках, де відповідно він становить від 75,04 до 83,81\%. Вміст білку коливається від 11,9 до 21,6 \%, найменший вміст у контрольному зразку. Це можна пояснити співвідношенням сировини та рослинних добавок.

Вміст жиру у готових пресервах склав від 3,21 до $3,27 \%$, що свідчить про позитивну дію на смакові властивості продукту.

За вмістом мінеральних речовин контроль містить $1,08 \%$. В дослідних зразках їх вміст змінюється від 3,58 до 5,51\%. Дослідні зразки відрізняються від контролю вмістом мінеральних речовин тому, що рослинні добавки містять велику кількість мінеральних речовин, які збагачують готовий продукт.

3 метою визначення смакових властивостей напівфабрикатів була проведена органолептична оцінка якості дослідних зразків упродовж усіх етапів виробництва до зберігання. Оцінювання проводили за власною розробленою 5 бальною шкалою. 
Дослідження органолептичних показників якості дослідних зразків напівфабрикатів протягом терміну зберігання наведені у таблиці 7.

Данні табл. 7 свідчать, що за органолептичними показниками впродовж 180 днів зберігання всі вироби мали на поверхні рівномірну рум'яну скоринку, збері- гали свою форму. Запах зразків зразок 1, 2 оцінений значно вищими балами, ніж прототипу, особливо зразок 2 через наявність спецій в його рецептурі. Запах прототипу після зберігання впродовж 90 днів охарактеризований як специфічний, рибний.

\section{Таблиця 6}

Загальний хімічний склад напівфабрикатів, \% $(\mathrm{n}=5, \mathrm{P} \leq 0,05)$

\begin{tabular}{lccc}
\hline \multirow{2}{*}{\multicolumn{1}{c}{ Найменування показників }} & \multicolumn{3}{c}{ Зразки напівфабрикатів } \\
\cline { 2 - 4 } Вонтроль & Зразок 1 & Зразок 2 \\
\hline Вміст вологи & $83,81 \pm 2,4$ & $75,04 \pm 2,3$ & $69,64 \pm 2,7$ \\
Вміст білку & $11,9 \pm 0,7$ & $18,1 \pm 0,9$ & $21,6 \pm 0,8$ \\
Вміст жиру & $3,21 \pm 0,22$ & $3,27 \pm 0,21$ & $3,24 \pm 0,23$ \\
Вміст мінеральних речовин & $1,08 \pm 0,14$ & $3,58 \pm 0,16$ & $5,51 \pm 0,16$ \\
\hline
\end{tabular}

\section{Таблиця 7}

Органолептична оцінка рибних напівфабрикатів на основі рослинної сировини, бали $(\mathrm{n}=5, \mathrm{P} \leq 0,05)$

\begin{tabular}{|c|c|c|c|c|c|c|}
\hline \multirow{2}{*}{$\begin{array}{c}\text { Найменування } \\
\text { зразків рецептур }\end{array}$} & \multirow{2}{*}{$\begin{array}{c}\text { Термін зберігання, } \\
\text { дні }\end{array}$} & \multicolumn{4}{|c|}{ Оцінка показників, бали } & \multirow{2}{*}{$\begin{array}{c}\text { Загальний } \\
\text { бал }\end{array}$} \\
\hline & & зовнішній вигляд & запах & консистенція & смак & \\
\hline \multirow{5}{*}{ контроль } & 30 & $4,8 \pm 0,4$ & $3,6 \pm 0,3$ & $4,6 \pm 0,3$ & $4,4 \pm 0,4$ & 17,4 \\
\hline & 60 & $4,8 \pm 0,4$ & $3,6 \pm 0,3$ & $4,6 \pm 0,4$ & $3,8 \pm 0,3$ & 16,8 \\
\hline & 90 & $4,8 \pm 0,4$ & $3,4 \pm 0,3$ & $4,4 \pm 0,4$ & $3,2 \pm 0,3$ & 15,8 \\
\hline & 135 & $4,6 \pm 0,4$ & $3,0 \pm 0,3$ & $4,0 \pm 0,3$ & $2,6 \pm 0,3$ & 14,2 \\
\hline & 180 & $4,4 \pm 0,3$ & $2,6 \pm 0,2$ & $3,8 \pm 0,3$ & $1,6 \pm 0,3$ & 12,4 \\
\hline \multirow{5}{*}{ Зразок 1} & 30 & $4,2 \pm 0,3$ & $4,8 \pm 0,4$ & $3,8 \pm 0,3$ & $5,0 \pm 0,4$ & 17,8 \\
\hline & 60 & $4,4 \pm 0,4$ & $4,8 \pm 0,4$ & $3,8 \pm 0,3$ & $4,8 \pm 0,3$ & 17,8 \\
\hline & 90 & $4,6 \pm 0,4$ & $4,8 \pm 0,3$ & $3,8 \pm 0,3$ & $4,6 \pm 0,4$ & 17,8 \\
\hline & 135 & $4,4 \pm 0,3$ & $4,6 \pm 0,3$ & $3,8 \pm 0,3$ & $4,4 \pm 0,4$ & 17,2 \\
\hline & 180 & $4,2 \pm 0,3$ & $4,6 \pm 0,4$ & $3,6 \pm 0,3$ & $3,8 \pm 0,3$ & 16,2 \\
\hline \multirow{5}{*}{ Зразок 2} & 30 & $4,8 \pm 0,4$ & $4,8 \pm 0,3$ & $4,4 \pm 0,4$ & $4,6 \pm 0,3$ & 18,6 \\
\hline & 60 & $4,6 \pm 0,4$ & $4,8 \pm 0,4$ & $4,2 \pm 0,3$ & $4,6 \pm 0,4$ & 18,2 \\
\hline & 90 & $4,2 \pm 0,3$ & $4,8 \pm 0,4$ & $4,2 \pm 0,3$ & $4,6 \pm 0,3$ & 17,8 \\
\hline & 135 & $4,4 \pm 0,3$ & $4,4 \pm 0,3$ & $4,0 \pm 0,3$ & $4,4 \pm 0,4$ & 17,2 \\
\hline & 180 & $4,2 \pm 0,3$ & $4,0 \pm 0,3$ & $4,0 \pm 0,3$ & $3,8 \pm 0,3$ & 16,0 \\
\hline
\end{tabular}

Ступінь накопичування жирних кислот в результаті гідролітичного розкладання ліпідів напівфабрикатів вивчали за зміною кислотного числа ліпідів. Результати досліджень представлені на рис. 1.

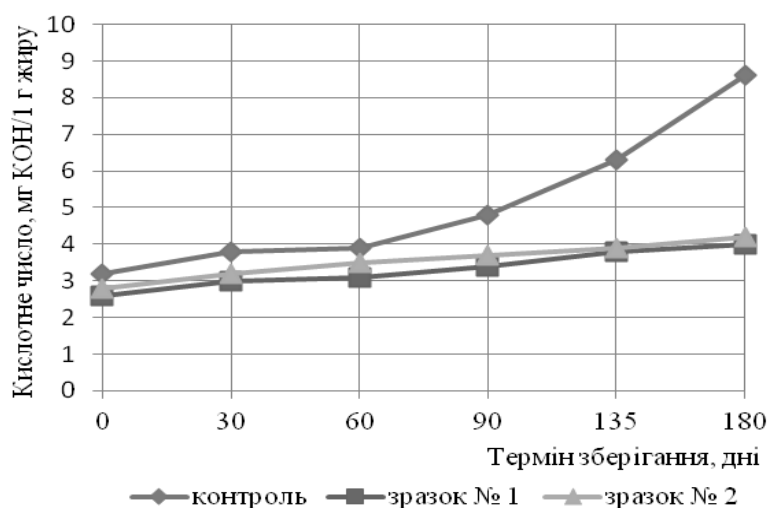

Рис. 1. Динаміка кислотного числа ліпідів напівфабрикатів

Дані рис. 3 свідчать, що зміни кислотного числа ліпідів напівфабрикатів під час зберігання протягом 180 днів при температурі мінус $18{ }^{\circ} \mathrm{C}$ мають лінійну тенденцію до збільшення.
Кислотні числа ліпідів контрольного зразка після 90 дня зберігання досягають 4,0 мг КОН/1 г жиру i продовжують збільшуватися, що свідчить про інтенсивний гідроліз ліпідів і накопичення вільних жирних кислот у цих зразках. Кислотне число ліпідів зразків 1, 2 впродовж 180 днів зберігання поступово збільшується і лише до кінця терміну зберігання (180 день) досягає 4 мг КОН/1 г жиру (Golembovskaya, 2018).

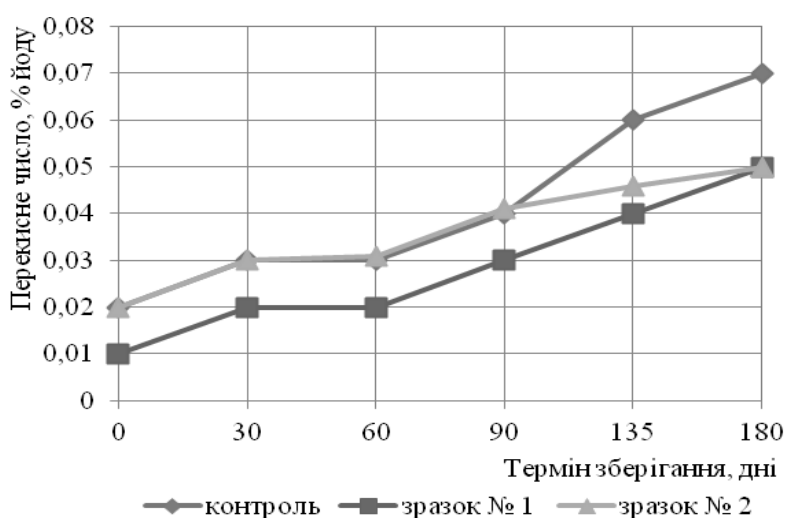

Рис. 2. Динаміка перекисного числа ліпідів напівфабрикатів 
Окислювальні процеси в ліпідах напівфабрикатів вивчали по змінах у накопичуванні первинних продуктів окислення - перекисів і вторинних продуктів карбонільних сполук. Результати досліджень змін перекисного числа ліпідів напівфабрикатів під час зберігання представлені на рис. 2.

В дослідних зразках накопичення первинних продуктів окиснення відбувалось найменш повільно у порівнянні $з$ контролем. Це зумовлено тим, що контрольні зразки рибних паличок містять більше жиру проти дослідних, шляхом великого вмісту у рецептурі рибної сировини.

\section{Висновки}

Розроблена технологія рибних напівфабрикатів, значно розширить асортимент продуктів функціонального призначення на основі природних компонентів, що дозволить, певною мірою, розширити актуальну проблему перероблення прісноводної риби.

Перспективи подальших досліджень. Отримані позитивні дослідження свідчать про продовження вивчення даної технології та потребують подальших розробок.

\section{References}

DSTU 2284-93. Ryba zhyva. Zahalni tekhnichni umovy. Diie z 1995.01.01. K.: Vyd-vo standartiv (in Ukrainian).

Golembovskaya, N. (2018). Research on changes of the quality indicators of semi-finished of dietary minced products during their storage. Scientific Messenger of LNU of Veterinary Medicine and Biotechnologies. Series: Food Technologies, 20(90), 17-21. doi: $10.32718 /$ nvlvet 9004 .
Golembovskaya, N. (2019). Usage of chia seeds in the composition of dietary semi-finished minced prod-ucts. Scientific Messenger of LNU of Veterinary Medicine and Biotechnologies. Series: Food Technologies, 21(92), 19-22. doi: 10.32718/nvlvet-f9204.

GOST 7631-85. Ryba, morskie mlekopitayushchie, morskie bespozvonochnye i produkty ih pererabotki. Pravila priemki, organolepticheskie metody ocenki kachestva, metody otbora prob dlya laboratornyh ispytanij. Dejstvuet z 1986.01.01. M.: Izd-vo standartov (in Russian).

GOST 7636-85. Ryba, morskie mlekopitayushchie, morskie bespozvonochnye i produkty ih pererabotki. Metody analiza. Dejstvuet z 1986.01.01. M.: Izd-vo standartov (in Russian).

Holembovska, N., Tyshchenko, L., Slobodyanyuk, N., Israelian, V., Kryzhova, Y., Ivaniuta, A., Pylypchuk O., Menchynska, A., Shtonda, O., \& Nosevych, D. (2021). Use of aromatic root vegetables in the technology of freshwater fish preserves. Potravinarstvo Slovak Journal of Food Sciences, 15, 296-305. doi: 10.5219/1581.

Ivaniuta, A., Menchynska, A., Nesterenko, N., Holembovska, N., Yemtcev, V., Marchyshyna, Y., Kryzhova, Y., Ochkolyas, E., Pylypchuk O., \& Israelian, V. (2021). The use of secondary fish raw materials from silver carp in the technology of structuring agents. Potravinarstvo Slovak Journal of Food Sciences, 15, 546-554. doi: 10.5219/1626.

Monastyrskij, K. (2004). Funkcional'noe pitanie. K. Monastyrskij. Ageless Press (in Russian).

Shapiro, D. K., Mancivodo, N. I., \& Mihajlovskaya, V. A. (2003). Dikorastushchie plody i yagody. M.: Urozhaj (in Russian). 